\title{
Evaluation of drought-tolerant sunflower (Helianthus annuus L.) hybrids in autumn and spring planting under semi-arid rainfed conditions ${ }^{\text {is }}$
}

\author{
Rao Muhammad Samran Gul ${ }^{1}$, Muhammad Sajid ${ }^{2}$, Saeed Rauf ${ }^{1, *}$, Hassan Munir ${ }^{2}$, \\ Muhammad Shehzad ${ }^{1}$ and Waseem Haider $^{1}$ \\ ${ }^{1}$ Department of Plant Breeding and Genetics, College of Agriculture, University of Sargodha, Sargodha, Punjab, Pakistan \\ 2 Department of Agronomy, University of Agriculture, Faisalabad, Pakistan
}

Received 28 September 2020 - Accepted 10 March 2021

\begin{abstract}
Global climate change is posing threats for sustainable crop production. Supra-optimal temperature and water stress are among few causes of global climate change which can cause significant damage to yield in various crop species including sunflower. Therefore, a study was initiated to develop new sunflower hybrids which may have higher seed yield and water use efficiency in current scenario of global climate change. Parental inbred lines were selected on the basis of cell membrane injury and cuticular waxes; these parental lines were used to develop various cross combinations. These cross combinations were evaluated at two locations and seasons. Some newly developed hybrids (H7, H8, H9) showed lesser days to flowering, high water use efficiency, high or comparable yield, kernel to seed $\%$ and oil contents $\%$ than high yielding commercial check Hysun.33. Water use efficiency (WUE) showed significant and high correlation with seed yield in both seasons. WUE decreased in spring season when compared with the autumn season due to high evapo-transpirational losses. General combining ability analyses showed that parental lines i.e. C.249 and RH.344 were the best combiners for water use efficiency and seed yield and may be exploited for the commercial development of drought resistant hybrids.
\end{abstract}

Keywords: combining ability / days to flowering / sustainable yield / water use efficiency

Résumé - Évaluation d'hybrides de tournesol (Helianthus annuus $L$.) tolérants à la sécheresse pour des semis d'automne et de printemps en conditions pluviales semi-arides. Le changement climatique mondiale menace la durabilité de la production agricole. Les températures supra-optimales et le stress hydrique figurent parmi les facteurs du changement climatique les plus pénalisants pour le rendement des cultures, dont le tournesol. C'est pourquoi, une étude a été menée pour développer de nouveaux hybrides de tournesol ayant un meilleur rendement et une meilleure efficience d'utilisation de l'eau dans les conditions actuelles marquée par le changement climatique. Des lignées parentales ont été sélectionnées sur la base des lésions de la membrane cellulaire et de la teneur en cires cuticulaires; ces lignées parentales ont été utilisées pour réaliser différents croisements. Ces derniers ont été évalués en deux lieux et pour deux dates de semis. En comparaison de la variété commerciale Hysun.33, à bonne productivité, certains hybrides nouvellement développés (H7, H8, H9) ont montré un nombre de jours pour atteindre la floraison inférieure, une haute efficience d'utilisation de l'eau, des valeurs de rendement, du rapport amande/akène et de la teneur en huile comparables ou plus élevées. L'efficience d'utilisation de l'eau (WUE) a montré une corrélation significative et élevée avec le rendement pour les deux saisons de culture. Les valeurs de WUE se sont avérées plus faibles au printemps qu'à l'automne, en raison de pertes élevées par évapotranspiration. Les analyses de l'aptitude générale à la combinaison ont montré que les lignées parentales, à savoir C.249 et RH.344, étaient les meilleures sources pour l'efficience d'utilisation de l'eau et le rendement et pourront être exploitées pour le développement commercial d'hybrides résistants à la sécheresse.

Mots clés : aptitude à la combinaison / nombre de jours pour atteindre la floraison / rendement durable / efficience d'utilisation de l'eau

\footnotetext{
th Contribution to the Topical Issue "Sunflower / Tournesol".

*Correspondence: saeedbreeder@hotmail.com
} 
Table 1. Cross combinations along with their codes and parental values of cell membrane injury and cuticular waxes.

\begin{tabular}{|c|c|c|c|c|c|}
\hline \multirow[t]{3}{*}{ Cross combinations } & \multirow[t]{3}{*}{ Codes } & \multicolumn{4}{|c|}{ Parental mean values } \\
\hline & & \multicolumn{2}{|c|}{ Cell membrane injury* } & \multicolumn{2}{|c|}{ Cuticular waxes $\left(\mu \mathrm{gg}^{-1}\right)$} \\
\hline & & Female & Male & $\overline{\text { Female }}$ & Male \\
\hline Hysun.33 & Hysun.33 & - & - & - & - \\
\hline C2728 $\times$ RFSS 88 & $\mathrm{H} 1$ & 0.58 & 0.59 & 611.80 & 716.39 \\
\hline C. $250 \times \mathrm{R} 345$ & $\mathrm{H} 2$ & 0.49 & 0.71 & 737.40 & 602.34 \\
\hline C. $208 \times$ R. 344 & H5 & 0.49 & 0.44 & 638.44 & 794.50 \\
\hline C. $259 \times$ R. .447 & H6 & 0.48 & 0.55 & 771.50 & 660.12 \\
\hline C. $259 \times$ R. 344 & $\mathrm{H7}$ & 0.48 & 0.44 & 771.50 & 794.50 \\
\hline C. $249 \times$ R. 447 & $\mathrm{H} 8$ & 0.43 & 0.55 & 782.34 & 660.12 \\
\hline C. $250 \times$ R. 344 & H9 & 0.49 & 0.44 & 737.40 & 794.50 \\
\hline
\end{tabular}

${ }^{*}$ Cell membrane injury induced by polyethylene glycol (40\%).

\section{Introduction}

Sunflower is a major oilseed crop which is cultivated around the globe for its seed, used for food (roasting, confectionery), animal feed and extraction of edible oil (Rauf, 2019). Sunflower is 4th major source of edible oil and contributes about $10 \%$ to the total global vegetable oil production (Rauf, 2019). Sunflower seed and oil has been considered among the healthiest diet due to rich source of various phytochemicals such as polyunsaturated fatty acids, tocopherols, sterols and micro elements (Selenium, Zinc and Iron) (Rauf et al., 2017; 2020).

Sunflower cultivation is challenged by global climate change which was marked by the sudden changes in temperature, heat waves, hail storms, strong winds and erratic rainfall which may threatens global sunflower cultivation (Debaeke et al., 2017). High temperatures also increased evapo-transpiration of sunflower which increase soil water extraction and the irrigational demand of crops (Rauf et al., 2016). Sunflower crop evapo-transpiration may increase up to 765 to $882 \mathrm{~mm}$ in 130 days in case of summer crop and daily evapo-transpiration has been estimated up to $13 \mathrm{~mm}$ day $^{-1}$ during flowering period under sub-tropical climate of Lebanon (Karam et al., 2007). Water productivity for sunflower crop ranged between $0.44-0.54 \mathrm{~kg} \mathrm{~m}^{-3}$ depending on the soil texture (Tolk and Howell, 2012). Highest production in Italy was achieved at $80-100 \%$ field capacity and generally sunflower crop exhausted about $40 \%$ of the soil moisture during entire growth cycle (Rinaldi et al., 2003). In subtropical conditions, with low and erratic rainfall and high temperature increases the chances of crop failures due to high evapotranspiration of sunflower during critical growth stages. These factors (low soil moisture and high temperature) may induce leaf senescence, gametophytic sterility, low grain filling, stunted growth of crops (Debaeke et al., 2017). Low soil moisture contents also caused decrease of above ground dry mass, harvest index and caused increase in lower ground dry mass (root mass) (Rauf and Sadaqat, 2008). Root mass seem to increase at the expense of above ground dry mass (Rauf and Sadaqat, 2008).

Conservation tillage and irrigational water has been used to reduce the deleterious effects of water stress during critical growth stages. Drip irrigation method or deficit irrigational practices have been recommended to reduce the impact of water stress on sunflower crop yield (Tolk and Howell, 2012). However, these practices may not be available or increase the cost of production for sunflower crop. Development of new cross combinations (hybrids) adapted to various environmental conditions may help to achieve sustainable yield under targeted condition (Kalyar et al., 2014). Therefore, parental lines selected against cell membrane injury due to polyethylene glycol mediated (40\%) osmotic stress and cuticular waxes, which may help to select drought resistant breeding lines having lower water losses (Shehzad et al., 2021) were used to develop cross combination which were evaluated at two locations and seasons with objectives to select developed hybrids with high seed yield and water use efficiency in comparison to commercial checks.

\section{Materials and Methods}

\subsection{Selection of parental materials and dvelopment of hybrids}

Parental inbred lines including cytoplasmic male sterile (CMS) and male fertility restorer lines (R) were screened on the basis of cell membrane injury induced through $40 \%$ polyethylene glycol (mol. Wt 8000) and leaf cuticular waxes. Inbred lines with significant lower cell membrane injury or higher leaf cuticular waxes and synchronization at flowering were used for the development of hybrids (Tab. 1). The selected inbred lines were maintained through sib mating by bagging capitula of two plants within inbred lines. Hybrid seed was produced by bagging the capitula of CMS (female) and R (male) inbred lines before anthesis and then manually pollinating the CMS lines with collected pollen from $\mathrm{R}$ line. 

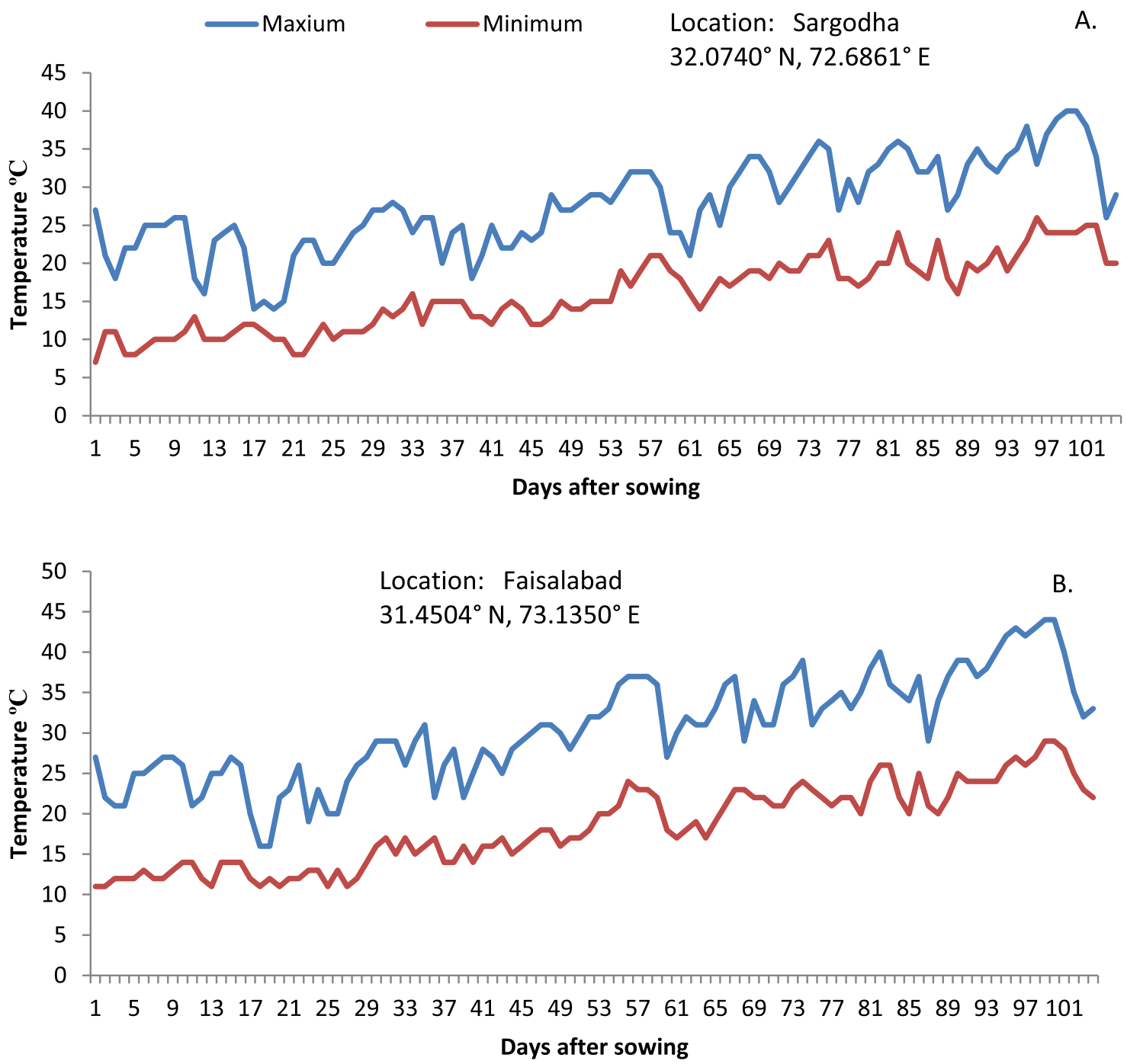

Fig. 1. Daily maximum and minimum temperature $\left({ }^{\circ} \mathrm{C}\right)$ of sunflower trials at two locations A. Sargodha B. Faisalabad during spring season 2020.

CMS and $\mathrm{R}$ lines were planted in 2:1. Capitula from CMS lines were harvested and dried. Seed was manually threshed, cleaned and stored at room temperature for raising hybrids.

\subsection{Growth conditions}

Two locations i.e. Sargodha and Faisalabad were chosen to evaluate the sunflower hybrid evaluation trials during spring and autumn seasons. Both locations are situated in central Punjab, Pakistan with annual double cropping system (wheat, rice, sugar cane and oilseed crops are grown). Site "Sargodha" was situated $32.0740^{\circ} \mathrm{N}, 72.6861^{\circ} \mathrm{E}$ at an elevation of $190 \mathrm{~m}$ while "Faisalabad" is located $31.4504^{\circ} \mathrm{N}, 73.1350^{\circ} \mathrm{E}$; elevation of $186 \mathrm{~m}$. Daily maximum and minimum temperatures of both sites and seasons during entire sunflower growth cycle is shown in Figures 1 and 2. Daily degree day accumulation at each site in both seasons is shown in Figure 3. Degree days were calculated by subtracting daily mean temperature from $7^{\circ} \mathrm{C}$ base temperature (the lowest temperature at which sunflower hybrids are able to germinate) (Qadir and Malik, 2007). Autumn season received a photoperiod of $8.5 \mathrm{~h}$ and $8 \mathrm{~h}$ for vegetative and reproductive phase while spring season had photoperiod of $7 \mathrm{~h}$ and $11 \mathrm{~h}$ during vegetative and reproductive phase respectively. Soil and environmental conditions of all experimental sites during spring and autumn season are summarized in Table 2 . Experiments were sown during August, 2019 and February, 2020 for Autumn and Spring crop respectively in randomized complete block design having 3 blocks. Distance between ridges was $75 \mathrm{~cm}$. There were four lines of $6 \mathrm{~m}$ for each hybrid within each line. Two seeds at distance of $22 \mathrm{~cm}$ were dibbled within each hole at depth of $5 \mathrm{~cm}$ with in each line, which was later thinned to single seedling upon germination to maintain 5 plants $\mathrm{m}^{-2}$. Inorganic fertilizer such as diammonium phosphate $\left(60 \mathrm{~kg} \mathrm{ha}^{-1}\right.$ and Urea $\left(40 \mathrm{~kg} \mathrm{ha}^{-1}\right)$ were added during soil preparation. Growth of weeds was check down by application of pre-emergence dual gold herbicide (S-metolachlor). A single irrigation was applied to have uniform germination; later on, trials were raised on natural rainfall at all experimental sites. Evapo-transpirational losses were estimat- 

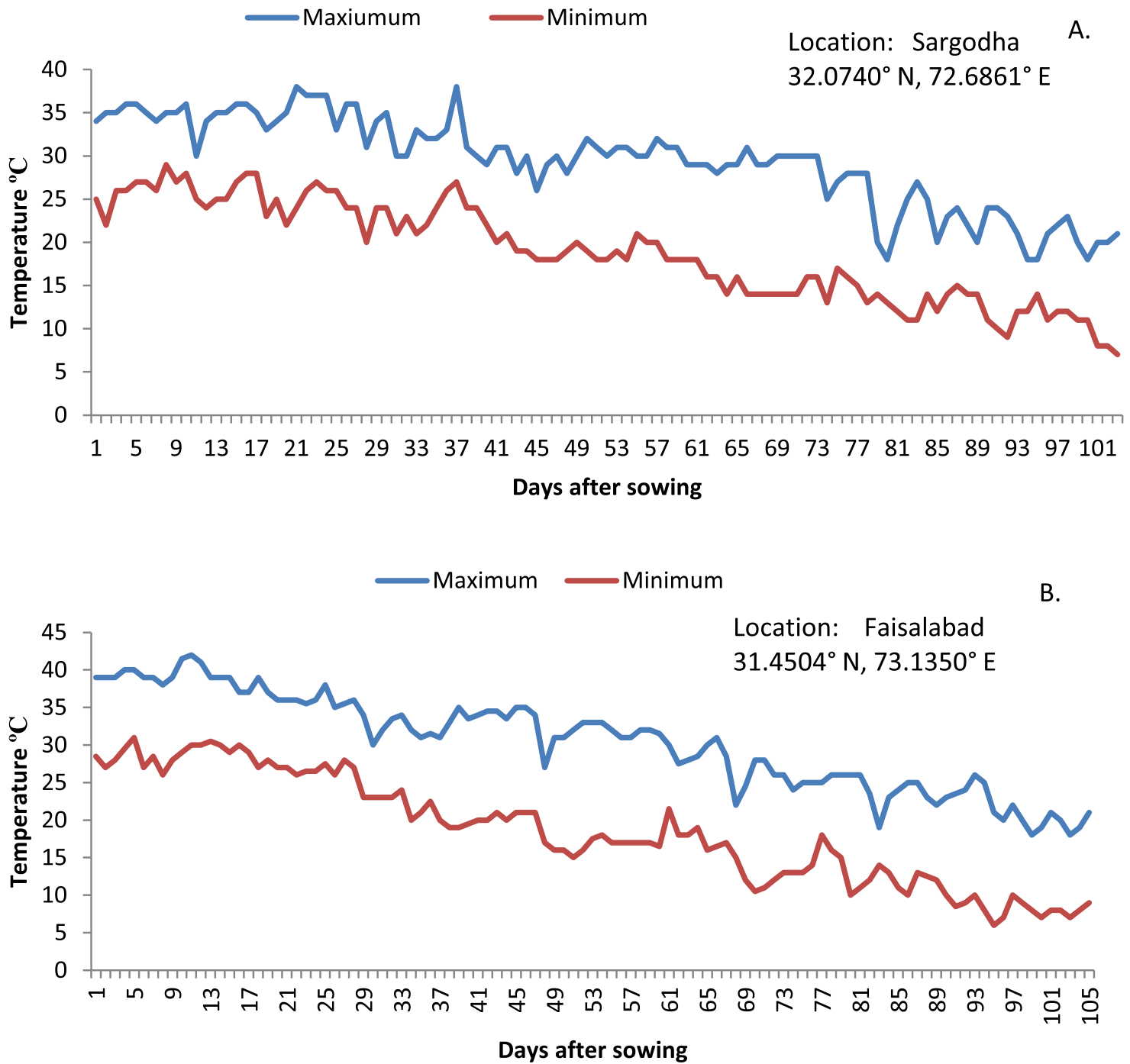

Fig. 2. Daily maximum and minimum temperature $\left({ }^{\circ} \mathrm{C}\right)$ of sunflower trials at two locations A. Sargodha B. Faisalabad during autumn season crop season 2019.

ed based on soil moisture losses at variable soil depths through gravimetric method. Total reproductive evaporational losses were determined from R1 (bud initiation) to R8 (pale yellow capitula). Soil moisture contents were multiplied with bulk density and soil depth to determine moisture contents in $\mathrm{mm}$. Spring season had higher transpirational losses as compared to autumn season. Recommended spray of pesticide (Lufenuron (Benzoylurea)@50 ml 100 L $\mathrm{L}^{-1}$ ) for armyworm was sprayed on spring crop to keep the insect population below threshold level.

\subsection{Parameter measurements}

Seed yield $\left(\mathrm{g} \mathrm{m}^{-1}\right)$ was determined by harvesting floral heads from 5 consecutive plants within each row. Heads were manually threshed, seed was cleaned and incubated at $40^{\circ} \mathrm{C}$ to determine seed yield at $10 \%$ seed moisture contents. Seed masses of each hybrid obtained from $1 \mathrm{~m}^{-1}$ rows were measured on digital balance. Leaf area of fully expanded leaves at top of canopy was measured at anthesis stage through digital leaf scanner (CI. 202, CID BioScience). Water use efficiency was ratio of dried seed mass to total evapotranspiration during floral initiation stage to final maturity of the hybrid. Floral initiation stage was button stage (R1) as described by Schneiter and Miller (1981). R1 stage was identified as having miniature floral bud with a star like appearance. Total Reproductive degree days accumulation was the sum of daily degree days from floral initiation stage to final maturity of reproductive capitula. Reproductive / total degree days was calculated by dividing total degree days during reproduction phase to total degree days accumulation during entire growth phase.

Kernel to seed \% was determined by dehulling $100 \mathrm{~g}$ of seed sample on disc rotary hulling machine. Kernel oil contents were determined by extracting oil from dehulled seed in Soxhlet apparatus. $15 \mathrm{~g}$ of dehulled (kernel) sample was crushed gently and loaded on the Soxhlet apparatus using nhexane as solvent. Samples were cycled through solvent until 

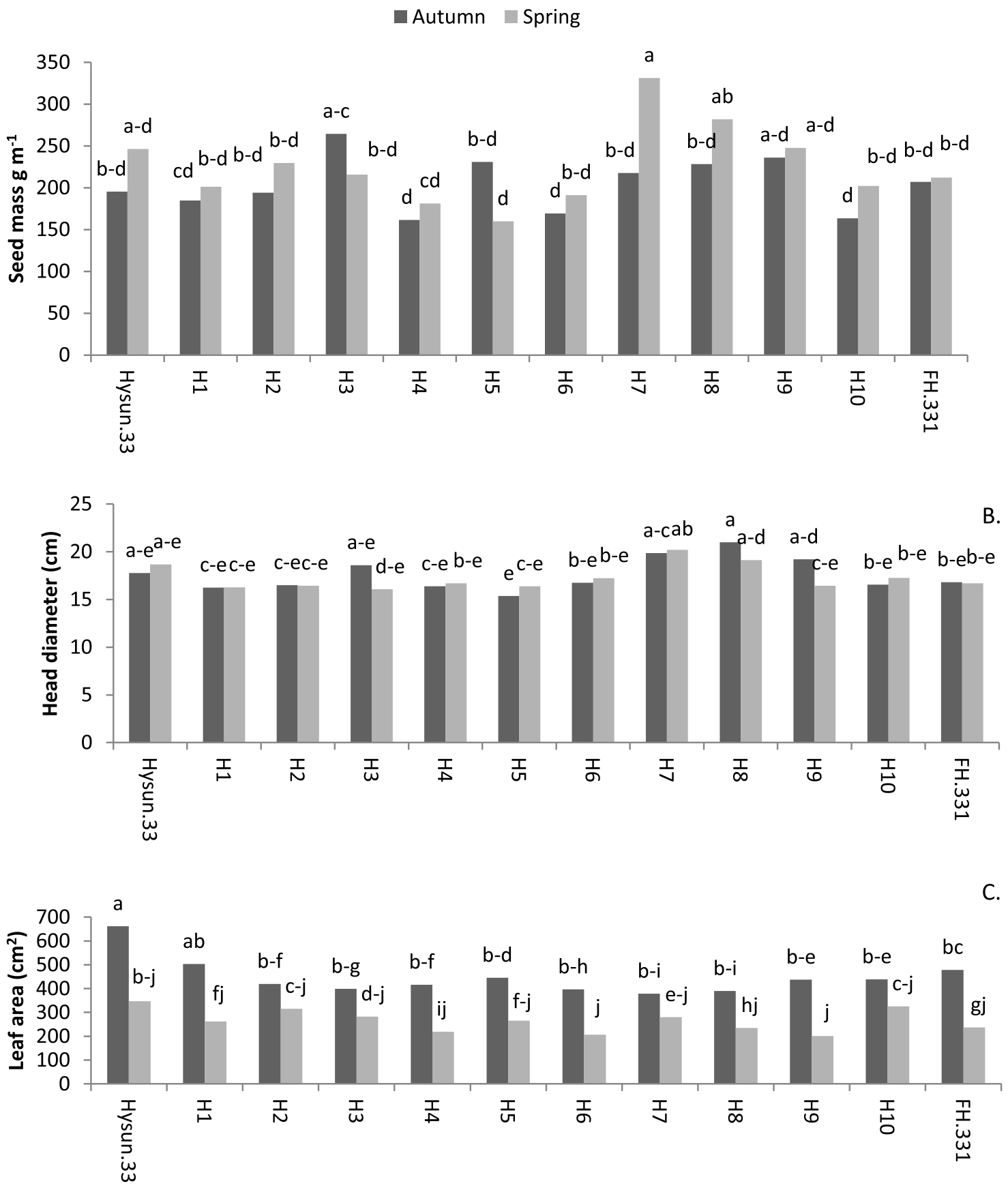

Fig. 3. Seed mass $\left(\mathrm{g} \mathrm{m}^{-2}\right)$, head diameter $(\mathrm{cm})$ and leaf area $\left(\mathrm{cm}^{2}\right)$ of various drought tolerant hybrids compared with the standard checks across two seasons. Means showing similar alphabet were statistically insignificant at $P \leq 0.05$. Alphabet i.e. a-d indicates range.

no further oil was recovered from each sample. Loaded sample was dried in oven at $40^{\circ} \mathrm{C}$ and decreased mass was determined on analytical balance to calculate the kernel oil \%.

\subsection{Statistical analyses}

Data was analysed under randomized complete block design with three replications. Mean of the hybrids were compared through least significant differences (LSD, $P \leq 0.05)$ test. Pearson correlation analysis was done to calculate relationship among morphological and phenological traits within each season. Significance of correlation was tested with two tail t-test (df-2). General combining ability values were calculated as per (Kempthorne, 1957). All statistical analysis was done on " $\mathrm{R}$ " software package (R Core Team, 2013).

\section{Results}

Analysis of variance showed significant $(P \leq 0.05)$ variations due to hybrids, locations and seasons for all traits under study (Tab. 3). Season $\times$ hybrids interaction was also significant $(P \leq 0.05)$ for all traits except head diameter 
R.M.S. Gul et al.: OCL 2021, 28, 24

Table 2. Soil and environmental conditions of experimental sites during spring and autumn season.

\begin{tabular}{|c|c|c|c|c|}
\hline Factor & \multicolumn{2}{|c|}{ Autumn } & \multicolumn{2}{|c|}{ Spring } \\
\hline Soil type & Sandy Clay loam & Sandy loam & Sandy Clay loam & Sandy loam \\
\hline $\mathrm{EC}\left(\mathrm{d} \mathrm{S} \mathrm{L}^{-1}\right)$ & $2.0 \pm 0.7$ & $1.39 \pm 0.08$ & $2.26 \pm 0.9$ & $1.72 \pm 0.6$ \\
\hline Water holding capacity (\%) & 18 & 17.5 & 18 & 17 \\
\hline Soil moisture $(80 \mathrm{~cm}) \%$ (grain filling) & 12.12 & 12.18 & 11.1 & 10.35 \\
\hline Water deficit (grain filling) $\%$ & 32.67 & 30.40 & 38.33 & 39.12 \\
\hline Organic matter $\left(\mu \mathrm{gg}^{-1}\right)$ & $7.22 \pm 0.24$ & $5.84 \pm 0.13$ & $6.61 \pm 0.21$ & $6.87 \pm 0.27$ \\
\hline Total Rain fall (mm) & 56 & 100 & 172 & 160 \\
\hline Reproductive rain fall & 25 & 20 & 36 & 39 \\
\hline Relative humidity (Vegetative phase) & 70 & 70 & 73 & 75 \\
\hline
\end{tabular}

Table 3. Analyses of variance for days to flowering (DTF), water use efficiency (WUE), seed yield (SY), head diameter (HD) and leaf area (LA).

\begin{tabular}{|c|c|c|c|c|c|c|}
\hline S.O.V. & \multicolumn{6}{|c|}{ Mean sum of square } \\
\hline Block & 2 & $5.80^{\mathrm{NS}}$ & $0.53^{\mathrm{NS}}$ & $12417.84^{*}$ & $18.75^{*}$ & $27659.84^{\mathrm{NS}}$ \\
\hline Season $(\mathrm{S})$ & 1 & $8063.44^{* *}$ & $35.69^{* *}$ & $9153.94^{\mathrm{NS}}$ & $9.27^{\mathrm{NS}}$ & $301843.41^{* *}$ \\
\hline Location (L) & 1 & $38.68^{* *}$ & $0.01^{\mathrm{NS}}$ & $2827.65^{\mathrm{NS}}$ & $2.02^{\mathrm{NS}}$ & $143319.23^{* *}$ \\
\hline $\mathrm{H} \times \mathrm{S}$ & 11 & $6.69^{*}$ & $0.89^{* *}$ & $12117.06^{*}$ & $5.98^{\mathrm{NS}}$ & $24231.93^{*}$ \\
\hline $\mathrm{S} \times \mathrm{L}$ & 1 & $861.44^{* *}$ & $0.63^{\mathrm{NS}}$ & 10134.03 & $45.85^{* *}$ & $46643.22^{\mathrm{NS}}$ \\
\hline $\mathrm{H} \times \mathrm{S} \times \mathrm{L}$ & 11 & $2.75^{\mathrm{NS}}$ & $0.70^{*}$ & 3800.04 & $1.39^{\mathrm{NS}}$ & $17262.44^{\mathrm{NS}}$ \\
\hline Residual & 94 & 2.17 & 0.27 & 3276.35 & 5.02 & 9360.68 \\
\hline Total & 143 & & & & & \\
\hline
\end{tabular}

showing that hybrids changed their relative ranking across all traits. However, crosses $\times$ locations interaction was only significant $(P \leq 0.05)$ for water use efficiency showing that hybrids did not change their ranking across locations (Tab. 3).

Seed yield of all hybrids was significantly $(P \leq 0.05)$ higher in spring season than autumn for all hybrids except $\mathrm{H} 3$ and $\mathrm{H} 5$ which showed higher seed yield during autumn season. Hybrids had $10 \%$ higher seed yield in spring than autumn season. Hybrids H9 and commercial check FH-331 had statistically similar yield in both seasons (Fig. 3a). H7 showed the highest yield during spring season followed by H8. H3 had the highest yield in autumn season. Hybrid H9 showed good yield in both seasons and may be further evaluated for commercialization under rained conditions. Head diameter was significantly different for hybrids such as $\mathrm{H} 3$ and $\mathrm{H} 9$ when compared in the seasons. Both hybrids had higher head diameter during autumn season when compared with spring season. $\mathrm{H} 7 \mathrm{had}$ the highest head diameter in both seasons
(Fig. 3b). Leaf area of hybrids was higher in autumn season when compared with spring season. Overall, hybrids in autumn season had $41 \%$ higher leaf area than spring season. This may be due to higher growing degree days in vegetative phase of autumn season. Overall autumn season had 153 higher degree days than spring season during vegetative phase. Hysun. 33 had the highest leaf area in both seasons (Fig. 3c).

Days to floral initiation were higher in spring season when compared with autumn season. Overall mean for days to floral initiation was 49 and 67 days for autumn and spring season crops. Flowering in spring season crop was 18 days late when compared with autumn season. The differences in days to floral initiation were due to temperature and photoperiod which may affect the circadian clocks within hybrids. Spring crop also had higher days to maturity. Autumn crop reached crop maturity 14 days earlier. Hysun. 33 took the highest days to initiate floral bud and maturity (Figs. 4a and 4b). FH.331 had the lowest days to floral initiation, while $\mathrm{H} 6$ took the lowest days to mature in spring season and thus 
Autumn Spring
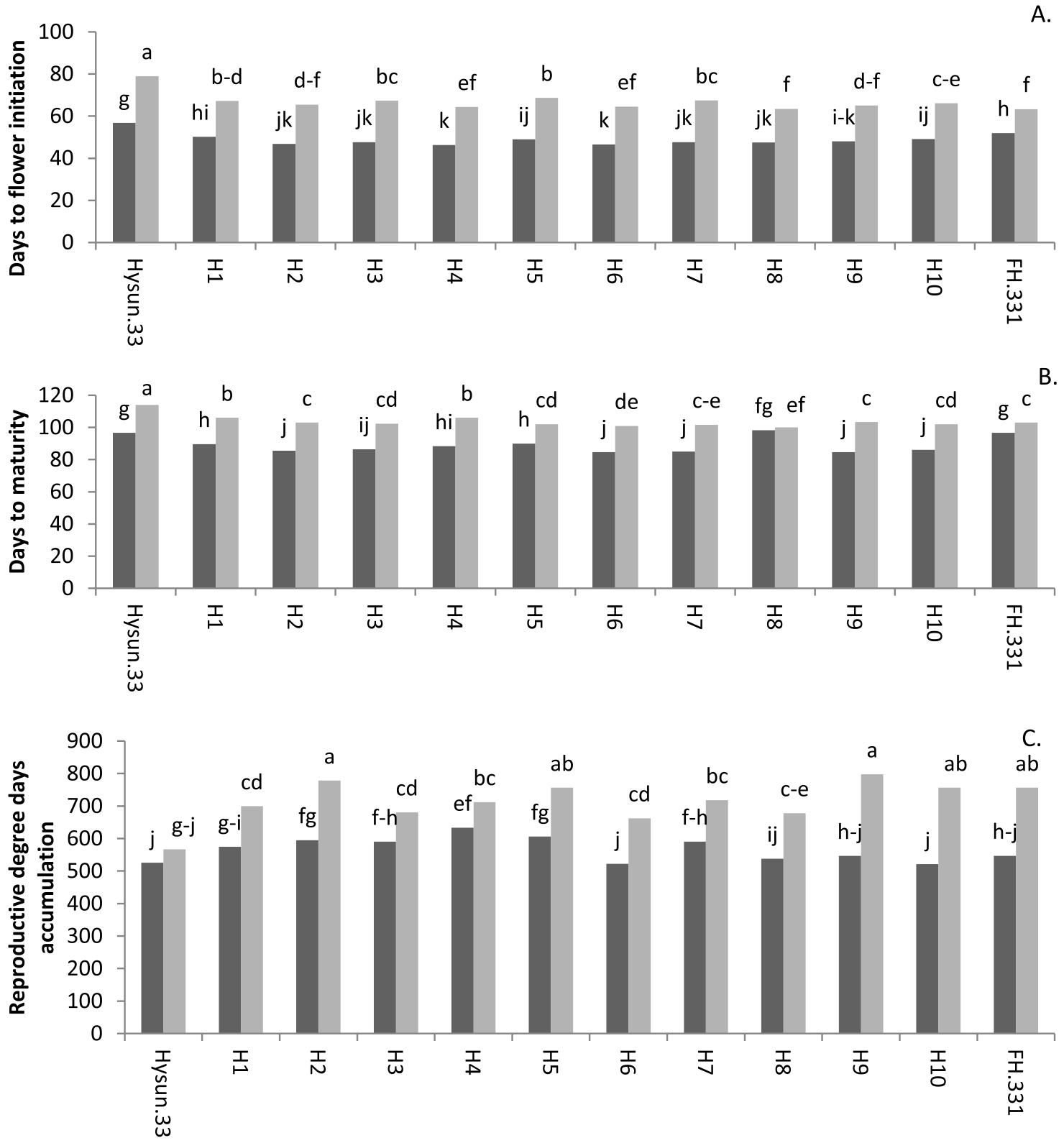

Fig. 4. A. Days to flower initiation B. Days to maturity and C. Reproductive degree days accumulation of various drought tolerant hybrids compared with the standard checks across two seasons. Means showing similar alphabet were statistically insignificant at $P \leq 0.05$. Alphabet $i . e$. $\mathrm{a}-\mathrm{d}$ indicates range.

may be categorized as early maturing hybrids during spring season (Figs. 4a and 4b). H4 and H6 had the lowest days to floral initiation while $\mathrm{H} 2, \mathrm{H} 6$ and $\mathrm{H} 7$ had the lowest days to maturity in autumn season (Figs. 4a and 4b). Development of early maturing hybrids has been an important breeding objective under double cropping systems. Late maturing hybrids delay cotton sowing (in cotton belt) during spring and wheat crop during autumn season. Reproductive degree days accumulation was higher in spring season (714 degree days) when compared with autumn (566 degree days) season which was $26 \%$ higher than autumn season. $\mathrm{H} 9$ and $\mathrm{H} 2$ had the highest degree days during spring season while $\mathrm{H} 4$ had the highest reproductive degree days (RDD) accumulation in autumn season (Fig. 4c).
There were significant $(P \leq 0.05)$ differences among the hybrids, seasons and their interaction for kernel to seed \%. Generally spring season had $6.4 \%$ higher kernel to seed $\%$ in spring season showing that hybrids potential increased for grain filling under spring seasons which may be due to higher photosynthate translocation to seed (Rauf and Sadaqat, 2008). All hybrids showed increased kernel to seed \% under spring season except $\mathrm{H} 3$ and $\mathrm{H} 9$ which showed contrasting response as they had higher kernel to seed\% in autumn season (Fig. 5a). H8 had the highest kernel to seed $\%$ in spring season while H9 showed the highest kernel to seed $\%$ in autumn season (Fig. 5a). Kernel oil \% was 7\% higher in spring season. It ranged between $40-49 \%$ and $34-49 \%$ during spring and autumn season 

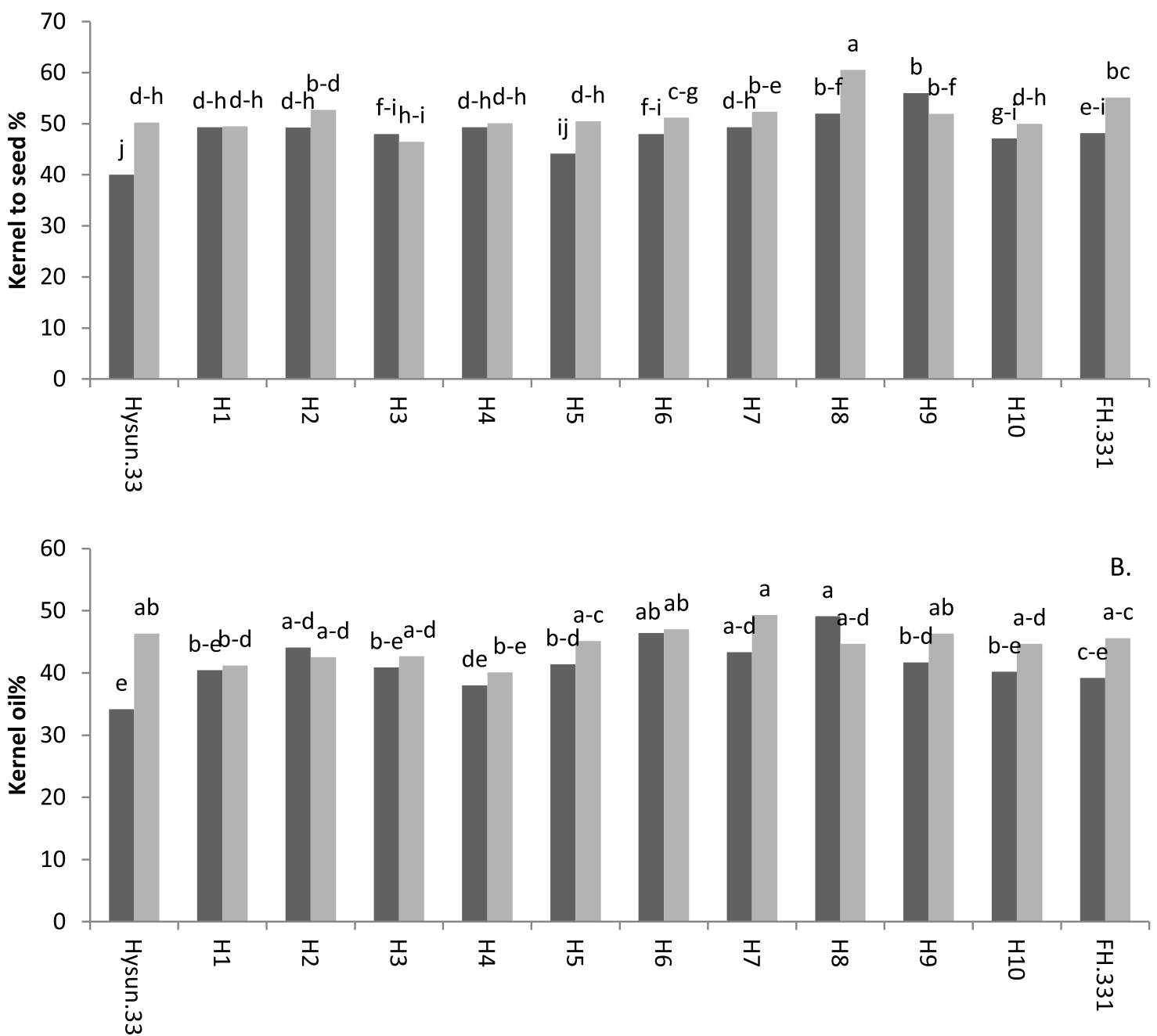

Fig. 5. A. Kernel to seed $\%$ and $6 \mathrm{~B}$. Kernel oil \% of drought tolerant hybrids compared with standard checks across two seasons. Means showing similar alphabet were statistically insignificant at $P \leq 0.05$. Alphabet i.e. a-d indicates range.

respectively (Fig. 5b). H8 had the highest kernel oil\% in autumn while $\mathrm{H} 7$ had the highest kernel oil\% during spring season (Fig. 5b).

Water use efficiency of hybrids was higher in autumn than spring season. Overall mean of hybrids for WUE were 2.44 and 1.32 in autumn and spring. Autumn crop had 86\% higher WUE than spring crop. High water use efficiency in autumn season was due to lower evapo-transpirational losses during entire reproductive phase. Sargodha location had higher WUE than Faisalabad. H7 had the highest WUE at Sargodha, while H9 had the similar WUE at both locations during autumn season. Hysun.33 showed the lowest WUE at Faisalabad during autumn season crop. H7 had the highest WUE at both locations during spring season (Fig. 6).

\section{General combining ability of parental lines}

General combining ability of breeding lines shows the performance of lines when cross pollinated with various breeding lines. A positive value of general combining means that breeding line did not carried recessive or deleterious alleles, so it may have potential to produce superior hybrids (Khalil et al., 2016). General combining ability (GC) analysis showed that C. 249 was best combiner for seed yield and water use efficiency. RH.344 and RH.345 were superior male breeding lines due to their positive GC values for seed yield and water use efficiency (Tab. 4).

\section{Correlation between morphological and phenological traits}

Pearson correlations were calculated over two locations within each season (Tab. 5). Seed yield (SY) was significantly $(P \leq 0.05)$ positively correlated with head diameter (HD) and water use efficiency (WUE) in both seasons showing both traits had positive contribution for SY (Tab. 5). SY had significant $(P \leq 0.05)$ negative correlation with reproductive to total degree days ratio (RDD/TDD) which showed that hybrids with higher seed yield had lower ratio in spring season and this correlation was insignificant under autumn season. This may be due to presence of terminal phase heat stress in spring 

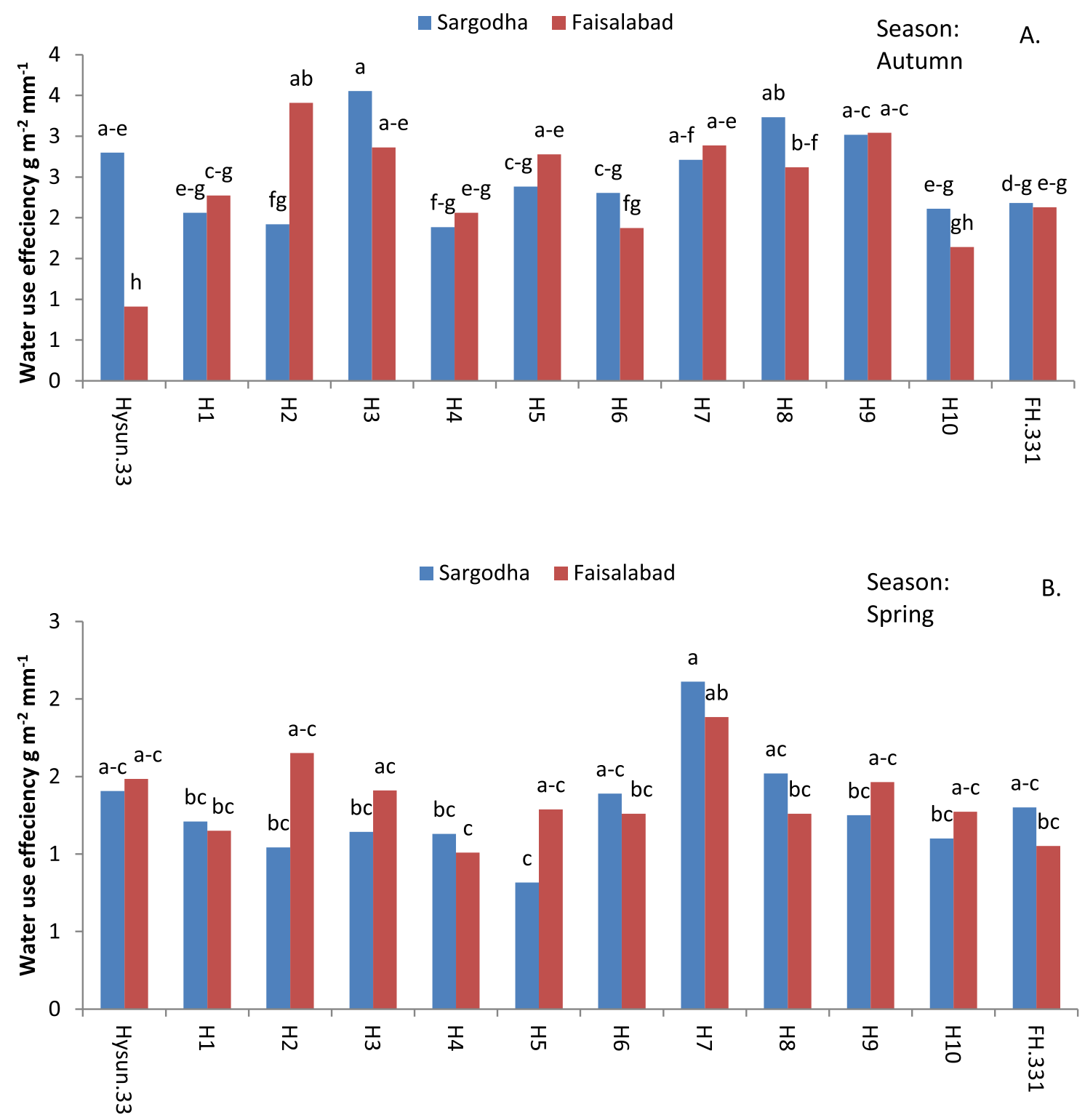

Fig. 6. Water use efficiency of drought tolerant hybrids compared with standard checks across two locations and two seasons A. Autumn B. Spring. Means showing similar alphabet were statistically insignificant at $P \leq 0.05$. Alphabet i.e. a-d indicates range.

season, which may have negatively affected the relationship between yield and reproductive degree days. Growing degree days to flowering (GDF) had positive relationship with days to flowering (DTF) in both season. Reproductive degree days had negative relationship with days to floral initiation under both seasons showing that hybrids with higher RDD had earlier flower initiation days. RDD also had negative relationship with days to maturity under spring season showing short growth cycle hybrids had higher RDD, which may be due to earlier flowering (Tab. 5). Days to maturity had negative but insignificant relationship with seed yield in spring season. Leaf area (LA) had significantly negative relationship with WUE in autumn season showing that higher leaf area would reduce the WUE in the hybrids more specifically during autumn season (Tab. 5). LA had positive significant correlation with growing degree days to flowering and days to flower initiation showing that hybrids with larger leaf area had delayed flowering in both season (Tab. 5).

\section{Discussion}

Drought tolerant parental lines (CMS), selected on the basis of $40 \%$ PEG induced cell membrane and cuticular waxes were mated with $\mathrm{R}$ lines to produce various hybrid combinations (Shehzad et al., 2021). Hybrid combinations from osmotic stress resistant parental lines along with two commercial checks were evaluated under two locations and seasons. Analysis of variance showed significant interactions of hybrids $\times$ seasons and insignificant interactions between locations which showed that broad adaptability of the hybrids 
R.M.S. Gul et al.: OCL 2021, 28, 24

Table 4. General combining ability values of promising parental lines used in the development of drought tolerant hybrids.

\begin{tabular}{|c|c|c|c|c|c|c|}
\hline \multirow[t]{2}{*}{ Parental lines } & \multicolumn{4}{|c|}{ Water use efficiency } & & \\
\hline & Sargodha & Faisalabad & Sargodha & Faisalabad & Autumn & Spring \\
\hline C. 2728 & -0.47 & -0.29 & -0.06 & -0.06 & -27.53 & -24.93 \\
\hline C. 250 & -0.09 & 0.24 & -0.10 & -0.10 & -2.77 & 10.34 \\
\hline C. 249 & 0.95 & 0.28 & 0.10 & 0.10 & 45.63 & 32.56 \\
\hline RFSS.88 & -0.38 & -0.18 & -0.02 & -0.02 & -15.87 & -14.92 \\
\hline R.345 & 0.29 & 0.68 & -0.14 & -0.14 & 28.57 & 6.39 \\
\hline RSIN.82 & -0.56 & -0.40 & -0.10 & -0.10 & -39.19 & -34.93 \\
\hline R.344 & 0.26 & 0.45 & 0.16 & 0.16 & 27.51 & 30.17 \\
\hline R.347 & -0.33 & -0.82 & -0.13 & -0.13 & -37.25 & -13.94 \\
\hline
\end{tabular}

Table 5. Pearson correlation coefficients among various morphological and phenological traits.

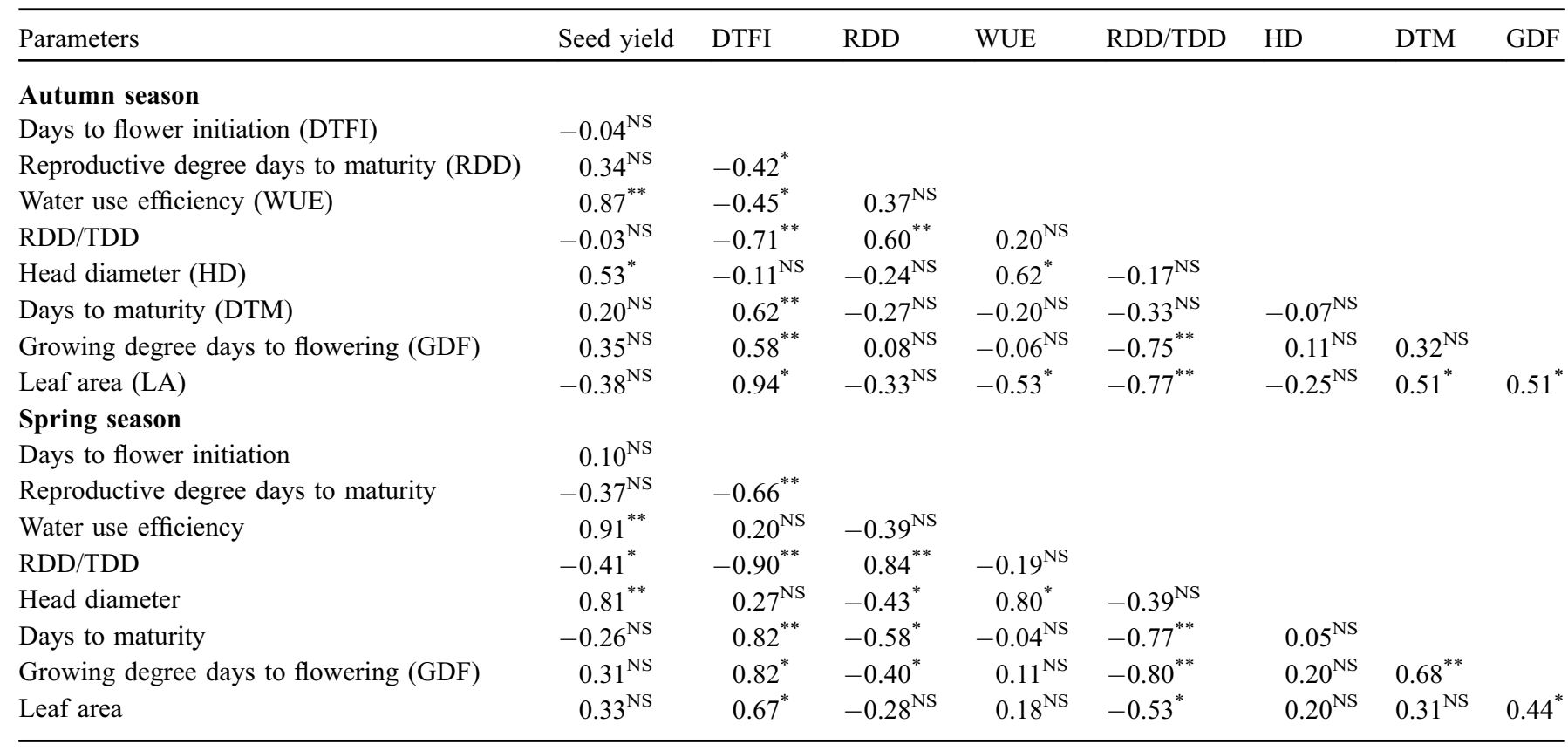

Where NS (non-significant); ${ }^{*}$ Significant $(P \leq 0.05) ; * *$ Highly significant $(P \leq 0.01)$.

was required to grow crop in two seasons of year (Chapman and De la Vega, 2002). Both seasons had wet vegetative phase with soil moisture contents close to field capacity of soil while low moisture contents during critical reproductive phases such as anthesis or grain filling. Newly developed hybrid combinations such as $\mathrm{H} 3, \mathrm{H} 7, \mathrm{H} 8$ and $\mathrm{H} 9$ were promising and had higher seed yield and greater water use efficiency than commercial checks in both seasons. H9 showed similar yield in both seasons and may have broad ability for both seasons.

Hybrids had higher yield during spring season as compared to autumn season. Both seasons had contrasting growth conditions especially during reproductive phase. Spring season had higher temperature and longer photoperiod during reproductive phase as compared with autumn season which may have affected the grain filling process in hybrids (Kalyar et al., 2014). The study was conducted in an environment where autumn season is marked by high temperature and photoperiod during vegetative phase of sunflower hybrids when compared with the spring season. High temperature and incident light during vegetative phase may have increased leaf area in autumn season (Pereyra-Irujo et al., 2008).

Hybrids showed higher water use efficiency in autumn season despite low yield in the season. High temperature increases evapo-transpiration of the hybrid, which peaked during reproductive phase making crop vulnerable to heat and water stress (Khan et al., 2016). Development of hybrids with reduced leaf area has been suggested to increase water use efficiency (Casadebaig et al., 2008). However, reduction in 
leaf area was known to reduce the photosynthetic capacity of plant and may negatively affect the yield during spring season. Alternatively, transpiration losses may be minimized by selection for high leaf cuticular waxes (Hussain et al., 2017; 2019). The parental lines in our earlier study conducted in hydroponic system were selected against cuticular waxes (Shehzad et al., 2021). WUE of newly developed hybrids was higher than commercial checks in spring environment, which may due to introgression of high cuticular waxes in hybrids (Fig. 6).

Hybrids sown in autumn season had earlier days to flowering than spring season. Days to flowering was an important trait to consider in breeding new hybrids and was known to depend on temperature and photoperiod. Heat units or growing degree days is temperature based response of development and used to assign a heat value to each phenological stage. High temperature or photoperiod may accelerate growing degree days accumulation process and may shorten the growth cycle of crop species (Parthasarathi et al., 2013). Days to flowering and growing degree days were known to be quantitative in inheritance and affected by several quantitative trait loci (León et al., 2001). Genes controlling the flowering in linkage groups A and B were found to be affected by the photoperiod (León et al., 2001). An early reproductive phase may counter the terminal low temperature and may also procure higher soil moisture contents during reproductive phase. This may explain high yield of the promising hybrids when compared with late maturing commercial checks such as Hysun.33. Late maturing hybrid (Hysun.33) was exposed on an average for 15 days to terminal heat stress of $38-40{ }^{\circ} \mathrm{C}$ as compared to newly developed hybrids, which were exposed to $8-10$ days terminal heat stress. Newly developed hybrids showed higher yield and entered reproductive phase earlier than commercial checks and accumulated higher reproductive degree days than commercial checks especially during autumn phase and reached physiological maturity earlier than commercial checks in spring season to escape from terminal phase heat stress. Earlier sowing dates has been recommended to ameliorate the effects of abiotic stress during terminal phase (García-López et al., 2016). However, erratic rainfalls generally hinder the field preparation under local conditions which may delay sowing times during spring and autumn crops. Hybrids which initiate early flowering during autumn season and short duration hybrids may be developed for general cultivation to avoid terminal phase heat stress and delay for cultivation of next crop.

General combining ability (GCA) value may be used to select parental lines which may be exploited in the hybrid breeding programs. Generally parental lines with GCA value carried positive alleles for the targeted traits and may be exploited in hybrid breeding program (Khalil et al., 2016). Parental line i.e. C.249 and R.344 were best combiner for water use efficiency and seed yield which may be exploited in development of commercial hybrids with broader adaptability.

\section{Ethical statement}

Manuscript meets all criteria for publication ethics.

\section{Conflict of interest}

Authors declare no conflict of interest.

Acknowledgement. This study is the part of the project entitled "Development of drought tolerant sunflower (Helianthus Annuus L.) hybrids for sustainable yield (PSF-MSRT II/Agr/PUoS(17)". Authors gratefully acknowledge Pakistan Science Foundation for funding this research.

\section{References}

Casadebaig P, Debaeke P, Lecoeur J. 2008. Thresholds for leaf expansion and transpiration response to soil water deficit in a range of sunflower genotypes. Europ J Agron 28(4): 646-654.

Chapman SC, De la Vega AJ. 2002. Spatial and seasonal effects confounding interpretation of sunflower yields in Argentina. Field Crop Res 73(2-3): 107-120.

Debaeke P, Casadebaig P, Flenet F, et al. 2017. Sunflower crop and climate change: vulnerability, adaptation, and mitigation potential from case-studies in Europe. OCL 24(1): 15.

García-López J, Lorite IJ, García-Ruiz R, et al. 2016. Yield response of sunflower to irrigation and fertilization under semi-arid conditions. Agric Water Manage 176: 151-162.

Hussain MM, Rauf S, Riaz MA, et al. 2017. Determination of drought tolerance related traits in Helianthus argophyllus, Helianthus annuus and their hybrids. Breed Sci J 67(3): 257-267.

Hussain MM, Rauf S, Warburton LM. 2019. Development of droughttolerant breeding lines derived from Helianthus annuus $\times \mathrm{H}$. argophyllus interspecific Crosses. Plant Breed 138(6): 862-870.

Kalyar T, Rauf S, Teixeira da Silva JA. 2014. Handling Sunflower (Helianthus annuus L.) populations under heat stress. Arch Agron Soil Sci 60: 655-672.

Karam F, Lahoud R, Masaad R, et al. 2007. Evapotranspiration, seed yield and water use efficiency of drip irrigated sunflower under full and deficit irrigation conditions. Agric Water Manage 90(3): 213-223.

Kempthorne O. 1957. An introduction of genetic statistics. New York, USA: John Willey \& Sons Inc., pp. 468-473.

Khalil F, Rauf S, Monneveux P, et al. 2016. Genetic analysis of proline concentration under osmotic stress in sunflower (Helianthus annuus L.). Breed Sci J 66: 463-470.

Khan M, Rauf S, Munir H, et al. 2016. Evaluation of sunflower (Helianthus annuus L.) single cross hybrids under heat stress condition. Arch Agron Soil Sci 63(4): 525-535.

León AJ, Lee M, Andrade FH. 2001. Quantitative trait loci for growing degree days to flowering and photoperiod response in sunflower (Helianthus annuus L.). Theoret Appl Genet 102(4): 497-503.

Parthasarathi T, Velu G, Jeyakumar P. 2013. Impact of crop heat units on growth and developmental physiology of future crop production: A review. J Crop Sci Tech 2(1): 2319-3395.

Pereyra-Irujo GA, Velázquez L, Lechner L, Aguirrezábal LA. 2008. Genetic variability for leaf growth rate and duration under water deficit in sunflower: analysis of responses at cell, organ, and plant level. J Exp Bot 59(8): 2221-2232.

Qadir G, Malik MA. 2007. Growing degree days and yield relationship in sunflower (Helianthus annuus L.). Int $J$ Agric Biol 9(4): 564-568.

R Core Team. 2013. R: A language and environment for statistical computing. Vienna, Austria: R Foundation for Statistical Computing. Available from http://www.R-project.org/. 
Rauf S. 2019. Breeding Strategies for Sunflower(Helianthus annuus L.) Genetic improvement. In: Advances in Plant Breeding Strategies: Industrial and Food Crops. Cham: Springer, pp. 637-673.

Rauf S, Sadaqat HA. 2008. Effect of osmotic adjustment on root length and dry matter partitioning in sunflower (Helianthus annuus L.) under drought stress. Acta Agric Scand Section B 58 (3): 252-260.

Rauf S, Al-Khayri JM, Zaharieva M, et al. 2016. Breeding strategies to enhance drought tolerance in crops. In: Al-Khayri JM, Jain MS, Johnson DV, eds. Advances in Plant Breeding Strategies: Agronomic, Abiotic and Biotic Stress Traits. Dordrecht: Springer Science + Business Media Dordrecht.

Rauf S, Jamil N, Tariq SA, et al. 2017. Progress in modification of sunflower oil to expand its industrial value. J Sci Food Agric 97: 1997-2006.
Rauf S, Ortiz R, Shehzad M, Haider W, Ahmed I. 2020. The exploitation of sunflower (Helianthus annuus L.) seed and other parts for human nutrition, medicine and the industry. Helia 43 (73): 167-184.

Rinaldi M, Losavio N, Flagella Z. 2003. Evaluation and application of the OILCROP-SUN model for sunflower in southern Italy. Agric Syst 78(1): 17-30.

Schneiter A, Miller JF. 1981. Description of sunflower growth stages. Crop Sci 11: 635-638.

Shehzad M, Gul RS, Rauf S, et al. 2021. Development of a robust hydroponic method for screening of sunflower (Helianthus annuus L.) accessions for tolerance to heat and osmotic stress. Sci Rep 11(1): 1-14.

Tolk JA, Howell TA. 2012. Sunflower water productivity in four Great Plains soils. Field Crop Res 127: 120-128.

Cite this article as: Gul RMS, Sajid M, Rauf S, Munir H, Shehzad M, Haider W. 2021. Evaluation of drought-tolerant sunflower (Helianthus annuus L.) hybrids in autumn and spring planting under semi-arid rainfed conditions. OCL 28: 24. 